\title{
慢性関節リウマチの関節外症状と免疫異常
}

\author{
中野 正明
}

Jpn. J. Clin. Immun., 14 (4) : 376 386, 1991.

\section{A clinical study of extra-articular lesions in rheumatoid arthritis patients}

\author{
Masaaki Nakano
}

Department of Medicine (II), Niigata University School of Medicine

\section{【Summary】}

The relationship between clinical, laboratory or immunological findings and extraarticular features were studied in 131 rheumatoid arthritis (RA) patients.

(1) The group without extra-articular complications (18 cases, 13.7\%); The mean age was more younger, and the mean duration of RA was more shorter in this group. Immunologically, the serum concentrations of complements were highest, compared with those of other groups.

(2) The group of malignant RA (MRA) or with interstitial pneumonia (22 cases, 16.8\%): The serum concentrations of $\mathrm{C}$-reactive protein $(\mathrm{CRP})$ and rheumatoid factors $(\mathrm{RF})$ were significantly higher in this group than those of patients without complications.

(3) The group with amyloidosis (17 cases, $13.0 \%$ ); They were also characterized by increased level of CRP. However, the serum IgG concentration was significantly lower in these cases. Proteinuria and impairment of renal function were observed in $13(76.5 \%)$ and 12 patients $(70.6 \%)$, respectively.

(4) The group complicated with other collagen vascular diseases such as systemic lupus erythematosus or mixed connective tissue disease (18 cases, 13.7\%); This group showed hypocomplementemia and hypergammaglobulinemia frequently.

(5) The group with histologically-proved renal lesions ( 30 cases, $22.9 \%$ ); Hematuria was found in 18 patients $(60 \%)$, proteinuria in $12(40 \%)$, and decreased renal function in $6(20 \%)$. Laboratory examinations revealed lower concentrations of CRP and RF, compared with those of other groups. No significant difference was observed in serum concentrations of immunoglobulin and RF among various nephropathies. These results suggests that the inflammatory and immunological processes may not have significant effects on the development of renal lesions in RA patients. 


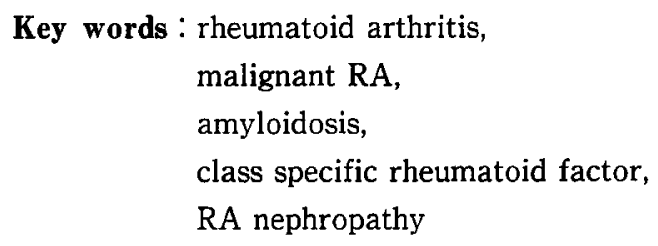

【概 要】

慢性関節りウマチ（RA）131 例について，関節外症状別に臨床背景，検査所見の比較検討を行った。悪性関 節リウマチ（MRA）あるいは間質性肺炎（IP）の合併例は 22 例であり, 疾患活動性やリウマトイド因子 (RF) が高值で, 予後不良であった。続発性のアミロイドーシスの合併は 17 例で, 疾患活動性は高值であった が, $\mathrm{RF}$ は低值であり, 蛋白尿や腎機能低下が各々 13 例, 12 例に観察され，最も予後不良であった。全身性工

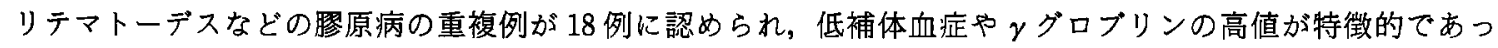
た. 一方, 組織学的に上記以外の腎障害の合併例は 30 例で, 血尿を 18 例に認めたものの, 蛋白尿や腎機能低下 の出現は低頻度で，予後は良好であった。検查所見では，疾患活動性とともにRF の低值が認められ，RAに認 められる腎障害は, MRA で観察される関節外症状とは異なり，RA 自体の炎症反応や免疫異常とは異なる成因 による障害であることが示唆された。

\section{I .はじめに}

慢性関節りウマチ（RA）は，破壊性，変形性の 骨・関節病変を主徵とする慢性炎症性の疾患である。 しかし,しばしば種々の関節外症状が出現し，予後の 点からも問題となっている.たとえば, 腎障害に関し ても, 従来, RAに続発するアミロイドーシス $(\mathrm{AM})^{1)}$, RA の治療薬剂による膜性腎症 ${ }^{2,3)}$, 全身性 エリテマトーデス (SLE) などの重複による障害4)な どが注目されていたが, 最近では, メザンギウム増殖 性系球体腎炎をはじめとして, 多彩な病変の存在が明 らかとなっている5,6).

一部の関節外症状では, リウマトイド因子 (RF) を主体とした免疫異常が重要な要因であると考えられ ているが, 腎障害などの関節外症状は，その成因が十 分に解明されていない. RA の種々の関節外症状にお ける, 臨床所見や免疫学的所見の特幑を検討すること は，その成因の解明のみならず，これらの鑑別や早期 診断からもきわめて重要と思われるが，この点に関す る成績は少なく，一定の結論も得られていない.

今回, 著者は, 腎障害を含めた RA の関節外症状 について, 臨床所見や免疫学的所見を検討し, 若干の 知見を得たので報告する.

\section{II. 対象・方法}

対象は, 昭和 54 年 4 月から平成 2 年 10 月までに, 新潟大学医学部附属病院第 2 内科に入院して精查を行 つた RA 131 例である. 131 例の性別は, 男性 34 例, 女性 97 例であり, 年齢は 20 歳から 79 歳, 平均 54.5 歳である.

検討方法としては，対象を主要な関節外症状別に分 け, 各群の臨床背景, 検查所見などを比較検討した。 臨床背景としては, 年齢, 性別, RA 罹病期間, RA 進行度，転帰などを検討した。また，検查所見では， 血沈値, 血清総蛋白, 蛋白分画, Laser nephelometry (LN) 法によるCRP, 血清免疫グロブ リン, 血清補体值のほか, 尿沈渣赤血球および 1 日尿 蛋白量, 腎機能, 腎組織所見, RF (LN 法および ELISA 法)を検討した。

ELISA 法によるIgM とIgA クラスの RF の測定 は, Bamptonら》の方法に準じて行った。すなわち, マイクロプレート (Nunc) に，ウサギIgG (Cappel) を固相し, Bovine serum albumin でブロ ック後, $56^{\circ} \mathrm{C} て ゙ 30$ 分間非働化した血清を 300 倍に希 釈して反応させた，次に，2次抗体として, Horseradish Peroxidase 標識の抗七トIgM, IgAのF $\left(\mathrm{ab}^{\prime}\right)_{2}$ 部分 (Cappel) を反応させ, O-phenylenediamine を含む基質液で呈色後, 硫酸で反応を停 
止させ, OD $492 \mathrm{~nm}$ における吸光度を測定した。ま た IgGクラスは, IgG-RF 測定キット（ED 001：エ ーザイ方) を使用した．この方法の概略は以下のごと くである.すなわち，七ト IgG-Fcを抗原とし，21 倍に希釈した血清を反応させ, Alkaliphos phatase 標識の抗ヒト IgG-Fd 2 次抗体として, 水酸化ナト リウムで反応を停止させ, OD $405 \mathrm{~nm}$ で吸光度を測 定する方法である，RFは，IgG-RF 测定キットに従 い, 指数化して定量的評価を行った。すなわち, 各測 定において，抗原を加えず同様に系を進めたブランク をおき，患者および健常人血清の OD值から，各々の ブランクの OD 值を差し引き, 患者の值を健常人の值 で除して指数化した。なお，健常人の值は，多数例の 平均值を用いた. IgG-RFは, 添付説明書に従い, 2.0 以上を陽性とし, IgM-RF, IgA-RFは, 健常人 の平均値 $+2 \mathrm{SD}$ を参考として，それぞれ $2.3 ， 2.1$ 以 上を陽性とした。

\section{III. 結 果}

対象としたRA 131 例は, 関節外症状別に以下の 6 群に分類した。

（1） I 群 (RA 単独群)：関節外症状を認めず，RA の診断精查あるいは加療目的の 18 例である.

(2) II 群 (MRA・IP 群)：厚生省研究班の悪性関節 リウマチ（MRA）の診断基準を满足する 13 例と, 間質性肺炎 (IP) を合併した 9 例, 計 22 例である. MRA 症例の多くが, IP を合併しているため, これ らを一括した。

(3) III群 (AM 群)：腎や消化管などの組織学的検 索で, AM の合併が診断された 17 例である.

（4） IV 群（腎障害群）：1 日蛋白尿 $0.5 \mathrm{~g}$ 以上ある いは尿沈渣赤血球が毎視野 5 個以上の尿検查異常の持 続，あるいは血清クレアチニン (Cr) $1.3 \mathrm{mg} / \mathrm{d} l$ 以 上の腎機能低下を有意の腎障害と規定し, 組織学的 に, AM 膠原病重複以外の腎障害と猃断された 30 例である。

（5） V 群（翏原病重複群）：臨床的あるいは組織学 的に, RAに他の膠原病が重複していると診断された 18 例である。この群は, RA以外に, 臨床的に SLE, 混合性結合組織病 (MCTD), 強皮症 (PSS) などの分類基準を満足した症例のほかに, 組織学的に ループス腎炎に合致した所見を呈する症例も含まれて いる，すなわち，蛍光抗体法で采球体内に各種の免疫 ク゚ロブリンや補体の沈着を認め, 電顕的には系球体係
蹄壁の内皮細胞側あるいは上皮細胞側, メザンギウム 領域などに多彩な沈着物を認め, さらに，内皮細胞内 にいわゆる microtubular structure が多数みられるな どの組織所見を呈した症例である.18例の内訳は, 組織学的な診断を含めた SLEの合併が 7 例, MCTD の合併が 4 例, PSS が 3 例, その他が 4 例であった。

(6) V群 (その他の合併症群)：前述の合併症でな く, 糖尿病や悪性腫瘍などの成人病, 感染症, 不整脈 などを合併した 26 例である。

なお，尿所見に異常を認めた MRA や IP 合併症は II群に含め, 同様に, 尿所見異常や腎機能障害を認め ても, $\mathrm{AM} の$ 合併あるいは琹原病の重複と判断され た症例や，その他の合併症を有する症例は，それぞれ III 群, V群， IV 群に分類した。

シェーグレン症候群（SjS）に関しては，耳鼻科あ るいは眼科的な検討が十分なされていない症例も多 く,とくに乾燥症状を欠く,いわゆる subclinical な 症例が検出されていない可能性もあり, 今回の検討か ら除外した。

以上のように 6 群に大別したが，以下の検討では， 関節外症状を認めないRA 単独群（I 群）を対照と して, 他の合併症群を比較した。

踟床背景（表 1) では, 男女比は, MRA・IP 群で 最も高く, $11: 11$ と男女同数であり, その他の合併 症群も比較的男性例が多かった。一方, AM 群と膠 原病重複群は, 女性が大部分を占めたが, 各群とも, $\mathrm{RA}$ 単独群に比較して有意差は認めなかつた。年齢 は, $\mathrm{AM}$ 群とその他の合併症群で平均 60 歳代と高 く, 膠原病重複群を除いて, 各群とも有意に高龄であ った. RA 単独群の平均年齢は 43.3 歳で, 対象症例 全体の平均年踰と比較しても, 10 歳以上も若い結果 であった。さらに， RA の痽病期間をみると， AM 群 で16.6 年と最も長く, 膠原病重複群がこれに続き, MRA・IP群を除いて, 対照より有意に長かった。ま た, RAの Stage 分類は, AM 群に扔いて, Stage III が 1 例, Stage $\mathrm{I}$ が 16 例であり, 進行度の平均は 3.9 と有意に高く, 膠原病重複群とその他の合併症群 でも, RA 単独群に比較して有意差を認めた.

次に, 各種の検査結果（表 1,2 )を，関節外症状 別に比較検討した，RA の疾㭧活動性の指標となる項 目（表 1) では, 赤沈值 $(\mathrm{mm} / \mathrm{h})$ は, MRA・IP 群 で平均 $85 \mathrm{~mm}$ と最も高く, 腎障害群が最も低い值を 示したが, 各群とも有意差は認めなかった。CRPも, $\mathrm{MRA} \cdot \mathrm{IP}$ 群で平均 $6.3 \mathrm{mg} / \mathrm{d} l$ と最も高く, $\mathrm{AM}$ 群 
表 1 各群の臨床背景と検亘所見の比較 (1)

\begin{tabular}{|c|c|c|c|c|c|c|}
\hline$(\mathrm{N})$ & $\begin{array}{l}\text { I 群 } \\
\text { (18) }\end{array}$ & $\begin{array}{l}\text { II 群 } \\
(22)\end{array}$ & $\begin{array}{l}\text { III群 } \\
\text { (17) }\end{array}$ & $\begin{array}{l}\text { IV 群 } \\
(30)\end{array}$ & $\begin{array}{l}\text { V 群 } \\
\text { (18) }\end{array}$ & $\begin{array}{l}\text { V群 } \\
(26)\end{array}$ \\
\hline $\begin{array}{c}\text { 男女比 } \\
\text { p }\end{array}$ & $\underset{\nVdash}{4: 14}$ & $\begin{array}{l}11: 11 \\
\text { NS }\end{array}$ & $\begin{array}{c}1: 16 \\
\text { NS }\end{array}$ & $\begin{array}{c}6: 24 \\
\text { NS }\end{array}$ & $\begin{array}{l}1: 17 \\
\text { NS }\end{array}$ & $\begin{array}{c}10: 16 \\
\mathrm{NS}\end{array}$ \\
\hline $\begin{array}{c}\text { 年齢（歳） } \\
\mathrm{p}\end{array}$ & $\begin{array}{l}43.3 \\
\approx\end{array}$ & $\begin{array}{l}58.7 \\
\hat{\imath}\end{array}$ & $\begin{array}{l}61.0 \\
\uparrow\end{array}$ & $\begin{array}{l}51.8 \\
\uparrow\end{array}$ & $\begin{array}{l}50.4 \\
\text { NS }\end{array}$ & $\begin{array}{l}61.7 \\
\hat{\imath}\end{array}$ \\
\hline $\begin{array}{c}\text { 罹病年数 } \\
\mathrm{p}\end{array}$ & $*^{4.9}$ & $\mathrm{NS}^{8.5}$ & $i_{i}^{16.6}$ & $\begin{array}{l}10.7 \\
\hat{\tau}\end{array}$ & $\operatorname{li}_{\hat{T}}^{13.7}$ & 10.2 \\
\hline $\begin{array}{l}\text { Stage（平均） } \\
\text { p }\end{array}$ & ${ }^{2.1}$ & $\begin{array}{l}2.6 \\
\text { NS }\end{array}$ & $\hat{i}^{3.9}$ & $\mathrm{NS}^{2.5}$ & $\uparrow^{2.7}$ & $\uparrow^{2.8}$ \\
\hline$\underset{p}{\underset{\mathrm{m}}{\mathrm{m}} \text { 沈 }}(\mathrm{mm} / \mathrm{h})$ & $\begin{array}{l}72 \\
*\end{array}$ & $\begin{array}{r}85 \\
\text { NS }\end{array}$ & $\begin{array}{r}78 \\
\text { NS }\end{array}$ & $\begin{array}{r}52 \\
\mathrm{NS}\end{array}$ & $\begin{array}{r}80 \\
\text { NS }\end{array}$ & $\begin{array}{r}64 \\
\text { NS }\end{array}$ \\
\hline$\underset{\mathrm{p}}{\mathrm{CRP}}(\mathrm{mg} / \mathrm{d} l)$ & $\varkappa^{4.6}$ & $\mathrm{NS}^{6.3}$ & $\mathrm{NS}^{5.4}$ & 1.4 & $\mathrm{NS}^{3.0}$ & $\mathrm{NS}^{3.5}$ \\
\hline$\underset{\mathrm{p}}{\alpha_{2}-\mathrm{gl}(\%)}$ & $\begin{array}{l}10.1 \\
*\end{array}$ & NS & $\begin{array}{l}12.1 \\
\text { NS }\end{array}$ & $\begin{array}{l}10.2 \\
\text { NS }\end{array}$ & $\mathrm{NS}^{8.4}$ & NS $^{9.3}$ \\
\hline $\begin{array}{l}\text { Lansbury 指数（\%） } \\
\text { p }\end{array}$ & $\begin{array}{l}72 \\
※\end{array}$ & $\begin{array}{r}75 \\
\text { NS }\end{array}$ & $\begin{array}{r}95 \\
\text { NS }\end{array}$ & $\begin{array}{r}50 \\
\text { NS }\end{array}$ & $\begin{array}{r}80 \\
\text { NS }\end{array}$ & $\begin{array}{r}59 \\
\text { NS }\end{array}$ \\
\hline$\underset{\mathrm{p}}{\operatorname{IgG}}(\mathrm{mg} / \mathrm{d} l)$ & $\begin{array}{c}1,813 \\
*\end{array}$ & $\begin{array}{r}1,937 \\
\mathrm{NS}\end{array}$ & $\begin{array}{r}1,501 \\
\mathrm{NS}\end{array}$ & $\begin{array}{r}1,487 \\
\text { NS }\end{array}$ & $\begin{array}{r}2,487 \\
\text { NS }\end{array}$ & $\begin{array}{r}1,941 \\
\mathrm{NS}\end{array}$ \\
\hline$\underset{\mathrm{p}}{\operatorname{IgA}}(\mathrm{mg} / \mathrm{d} l)$ & $\begin{array}{l}317 \\
\nVdash\end{array}$ & $\begin{array}{c}488 \\
\uparrow\end{array}$ & $\begin{array}{l}371 \\
\text { NS }\end{array}$ & $\begin{array}{l}366 \\
\text { NS }\end{array}$ & $\begin{array}{l}441 \\
\text { NS }\end{array}$ & $\begin{array}{l}439 \\
\text { NS }\end{array}$ \\
\hline$\underset{\mathrm{p}}{\operatorname{IgM}}(\mathrm{mg} / \mathrm{d} l)$ & $\begin{array}{c}149 \\
*\end{array}$ & $\begin{array}{l}189 \\
\text { NS }\end{array}$ & $\begin{array}{l}257 \\
\text { NS }\end{array}$ & $\begin{array}{l}146 \\
\text { NS }\end{array}$ & $\begin{array}{l}231 \\
\text { NS }\end{array}$ & $\begin{array}{l}237 \\
\text { NS }\end{array}$ \\
\hline C $3 \underset{\mathrm{p}}{3}(\mathrm{mg} / \mathrm{d} l)$ & $\begin{array}{l}109 \\
*\end{array}$ & $\begin{array}{l}81 \\
\text { I }\end{array}$ & $\begin{array}{l}72 \\
\text { 』 }\end{array}$ & $\begin{array}{l}87 \\
\&\end{array}$ & $\begin{array}{l}58 \\
\sqrt{ }\end{array}$ & $\begin{array}{l}75 \\
\Omega\end{array}$ \\
\hline
\end{tabular}

$\uparrow, \downarrow: p<0.05$ vs $*$ $\uparrow, \S: p<0.01$ vs $\approx$

が,これに次いで高値を示したが，有意差はなく，反 対に腎障害群は, $1.4 \mathrm{mg} / \mathrm{d} l$ と有意に低い值であっ た. $\alpha_{2}$-Globulin 分画は，各群とも $10 \%$ 前後であり， 有意の差異は認めなかった。一方, Lansbury 指数 は, AM 群で $95 \%$ と最も高く, 腎障害群で最も低い 值であったが, 有意差は認めなかった。

免疫グロブリンおよび補体（表 1) では，IgG（正 常 $889 \sim 1,968 \mathrm{mg} / \mathrm{d} l$ ) は, 膠原病重複群で2,487 $\mathrm{mg} / \mathrm{d} l$ と最も高值であり, 反対に腎障害群 1,487 $\mathrm{mg} / \mathrm{d} l$, AM 群 $1,501 \mathrm{mg} / \mathrm{d} l$ の順に低値であったが, いずれも有意差は認めなかった. IgA（正常 93〜380 $\mathrm{mg} / \mathrm{d} l$ ) は, MRA・IP 群で $488 \mathrm{mg} / \mathrm{d} l$ と最も高く, 有意差を認めた. IgM (正常 $50 \sim 290 \mathrm{mg} / \mathrm{d} l$ ) は, $\mathrm{AM}$ 群で最も高い值を示したが，それ以外の群を含 めて, 有意差はなかった。一方, C 3 （正常 $55.3 \sim 140.0 \mathrm{mg} / \mathrm{d} l)$ は, RA 単独群で平均 $109 \mathrm{mg} /$ $\mathrm{d} l$ と最も高く, 反対に膠原病重複群では $58 \mathrm{mg} / \mathrm{d} l$
と最も低く, AM 群, その他の合併症群の順につづ き, 各群とも有意に低值であった。

$\mathrm{LN}$ 法による RF（表 2）は， MRA・IP 群で平均 $731 \mathrm{IU} / \mathrm{m} l$ と最も高く, 反对に, 腎障害群が $95 \mathrm{IU} /$ $\mathrm{m} l$ と, 最も低い值を示したが, MRA・IP 群のみ有意 差を認めた. MRA ・ IP 群は, 各クラスの RF も有意 に高い值を示し, IgG-RFはAM 群で最も低く, IgM-RF と IgA-RF は, 腎障害群で最も低い值を示 したが，いずれも有意差は認めなかった。なお， RA 単独群と MRA ・ IP 群とのクラス別 RF の有意差は, IgGクラスで最も強く認められた。

次に，尿所見異常および腎機能障害（表 2 ）に関し て検討したが, RA 単独群にも, 1 日 $0.5 \mathrm{~g}$ 以下の微 量の蛋白尿や一過性の血尿を認めた症例が含まれてい る. 1 日 $0.5 \mathrm{~g}$ 以上の蛋白尿は, 全体では29例 （22.1\%）に陽性であった. 関節外症状別では，AM 群で, 17 例のうち 13 例 (76.5\%), 腎障害群で, 30 
表 2 各群の臨床背景と検査所見の比較 (2)

\begin{tabular}{|c|c|c|c|c|c|c|}
\hline & I 群 & II群 & III群 & IV 群 & V群 & VI群 \\
\hline$\underset{\mathbf{p}}{\mathrm{LN}-\mathrm{RF}}(\mathrm{IU} / \mathrm{m} l)$ & $\begin{array}{r}179 \\
*\end{array}$ & $\begin{array}{r}731 \\
\uparrow\end{array}$ & $\stackrel{254}{\text { NS }}$ & $\begin{array}{l}95 \\
\text { NS }\end{array}$ & $\stackrel{208}{\text { NS }}$ & $\begin{array}{l}515 \\
\text { NS }\end{array}$ \\
\hline$\underset{\mathrm{p}}{\mathrm{IgG}-\mathrm{RF}}$ & $\begin{array}{l}1.7 \\
*\end{array}$ & $\begin{array}{l}4.5 \\
\hat{\tau}\end{array}$ & $\begin{array}{l}1.4 \\
\text { NS }\end{array}$ & $\begin{array}{l}2.0 \\
\text { NS }\end{array}$ & $\begin{array}{c}3.8 \\
\uparrow\end{array}$ & $\begin{array}{l}2.6 \\
\text { NS }\end{array}$ \\
\hline$\underset{p}{\operatorname{IgM}}$ & $\begin{array}{l}6.8 \\
*\end{array}$ & 17.3 & $\begin{array}{l}6.9 \\
\text { NS }\end{array}$ & $\begin{array}{l}4.0 \\
\text { NS }\end{array}$ & $\begin{array}{l}8.3 \\
\mathrm{NS}\end{array}$ & $\begin{array}{l}10.8 \\
\mathrm{NS}\end{array}$ \\
\hline$\underset{p}{\operatorname{IgA}-R F}$ & $\begin{array}{l}6.5 \\
*\end{array}$ & 15.3 & $\begin{array}{l}6.7 \\
\text { NS }\end{array}$ & $\begin{array}{l}3.5 \\
\text { NS }\end{array}$ & $\begin{array}{l}7.4 \\
\text { NS }\end{array}$ & $\begin{array}{l}9.1 \\
\text { NS }\end{array}$ \\
\hline$\underset{\mathrm{p}}{\text { 尿蛋白 } \geqq 0.5 \mathrm{~g} / \text { 日 }(\%)}$ & $\begin{array}{l}0 \\
*\end{array}$ & $\begin{array}{c}5 \\
\text { NS }\end{array}$ & $\begin{array}{c}73 \\
\hat{\tau}\end{array}$ & 40 & $\begin{array}{l}11 \\
\text { NS }\end{array}$ & $\begin{array}{c}4 \\
\text { NS }\end{array}$ \\
\hline$\underset{\mathrm{p}}{\text { 尿蛋白（g/日） }}$ & $\begin{array}{l}0.04 \\
\approx\end{array}$ & $\begin{array}{l}0.12 \\
\text { NS }\end{array}$ & $\underbrace{2.80}_{\hat{\imath}}$ & $\begin{array}{l}1.69 \\
\hat{\imath}\end{array}$ & $\begin{array}{l}0.29 \\
\text { NS }\end{array}$ & $\begin{array}{l}0.04 \\
\text { NS }\end{array}$ \\
\hline$\underset{\mathrm{p}}{\text { 血尿陽性例*（\%) }}$ & 11 & $\stackrel{23}{\text { NS }}$ & $\begin{array}{r}44 \\
\uparrow\end{array}$ & 60 & $\stackrel{22}{\text { NS }}$ & $\begin{array}{l}8 \\
\text { NS }\end{array}$ \\
\hline$\underset{\mathrm{p}}{\mathrm{m}}$ 清 $\mathrm{Cr} \geqq 1.3 \mathrm{mg} / \mathrm{d} l(\%)$ & $\begin{array}{l}0 \\
*\end{array}$ & $\begin{array}{c}0 \\
\text { NS }\end{array}$ & 71 & 20 & $\begin{array}{l}6 \\
\text { NS }\end{array}$ & $\stackrel{8}{\mathrm{NS}}$ \\
\hline$\underset{\mathrm{p}}{\text { 血清 } \mathrm{Cr}(\mathrm{mg} / \mathrm{d} l)}$ & $\begin{array}{l}0.76 \\
*\end{array}$ & $\begin{array}{l}0.75 \\
\text { NS }\end{array}$ & $\operatorname{\tau }_{\widehat{\tau}}^{2.38}$ & $\begin{array}{l}0.97 \\
\mathrm{NS}\end{array}$ & $\begin{array}{l}0.68 \\
\text { NS }\end{array}$ & $\begin{array}{l}0.87 \\
\text { NS }\end{array}$ \\
\hline $\begin{array}{l}\text { 血清総蛋白（g/d } l) \\
\mathrm{p}\end{array}$ & $\begin{array}{l}7.5 \\
*\end{array}$ & $\begin{array}{l}7.1 \\
\text { NS }\end{array}$ & $\begin{array}{l}5.9 \\
3\end{array}$ & $\begin{array}{l}6.7 \\
\&\end{array}$ & $\begin{array}{l}7.4 \\
\text { NS }\end{array}$ & 7.0 \\
\hline$\underset{p}{\text { Albumin }}(\%)$ & $\begin{array}{c}51.6 \\
*\end{array}$ & $\begin{array}{c}46.6 \\
\downarrow\end{array}$ & $\begin{array}{l}49.5 \\
\text { NS }\end{array}$ & $\begin{array}{l}53.6 \\
\text { NS }\end{array}$ & $\begin{array}{l}48.2 \\
\text { NS }\end{array}$ & $\begin{array}{l}52.4 \\
\text { NS }\end{array}$ \\
\hline$\underset{\mathrm{p}}{\boldsymbol{y} \text {-Globulin }(\%)}$ & $\begin{array}{c}23.4 \\
*\end{array}$ & $\begin{array}{c}26.9 \\
\text { NS }\end{array}$ & $\begin{array}{c}23.5 \\
\text { NS }\end{array}$ & $\begin{array}{c}21.0 \\
\text { NS }\end{array}$ & $\begin{array}{c}30.4 \\
\uparrow\end{array}$ & $\begin{array}{c}24.2 \\
\text { NS }\end{array}$ \\
\hline
\end{tabular}

* 沈査赤血球毎視野 5 個以上

例のうち 12 例 $(40.0 \%)$ の頻度であり,この二群は 有意に高頻度であり，AM 群は，留障害群と比較し ても有意に頻度が高かった，その他では, 膠原病重複 群で 2 例, MRA - IP 群とその他の合併症群で各 1 例 に, 有意の蛋白尿が認められた。一方, 尿沈渣中の赤 血球が毎視野 5 個以上の血尿は, 全体では 39 例 (29.8\%) に認められた。各群では，腎障害群で，30 例のうち 18 例 $(60 \%), \mathrm{AM}$ 群で 17 例のうち 8 例 （47.1\%）が陽性であり，この二群間には有意差は認 めなかったが, それぞれ, 対照に比べて有意に頻度が 高かった。なお，MRA・IP 群で尿異常が認められた 5 例（21.7\%）では，1例で蛋白尿と血尿を認めた が，他の 4 例は血尿単独の尿異常であった. 2 例に腎 生検が行われたが, 1 例は微小変化型であり, 他の 1 例はびまん性メザンギウム増殖性系球体腎炎で, 蛍光 抗体法で IgA 腎炎の所見が認められた。

また，血清 Cr $1.3 \mathrm{mg} / \mathrm{d} l$ 以上の腎機能低下例は， $\mathrm{AM}$ 群では，17 例のうち 12 例 $(70.6 \%)$ に認められ
た。しかし，腎障害群では，30例のうち 6 例 (20.0\%) と比較的頻度が低く，この二群は有意に頻 度が高かったが、両群間にも有意差が認められた。血 清 $\mathrm{Cr}$ の上昇は, MRA・IP 群にはなく, その他の合併 症群, 噖原病重複群では, それぞれ 2 例, 1 例に認め られ，全体では 21 例 (16.0\%) に観察された。血清 $\mathrm{Cr}$ の平均值も, $\mathrm{AM}$ 群が $2.38 \mathrm{mg} / \mathrm{d} l$ と有意に高く, 腎障害群を含めた他の群は, 対照に比べて有意差は認 めなかった。

血清総蛋白（表 2 ）は, RA 単独群で $7.5 \mathrm{~g} / \mathrm{d} l$ と 最も高く, 一方, AM 群 $5.9 \mathrm{~g} / \mathrm{d} l$, 腎障害群 $6.7 \mathrm{~g} /$ $\mathrm{d} l$, その他の合併症群 $7.0 \mathrm{~g} / \mathrm{d} l$ の順に低く, それぞ れ有意差が認められた. Albumin 分画は, MRA・IP 群が 46.6\%で, 対照に比べて有意に低值であったが, 他の群では有意差は認めなかった。また， $\gamma$ Globulin 分画は, 膠原病重複群が $30.4 \%$ と高值を示 し，有意差を認めた。

次に, 腎障害群 30 例を組織型別に分けて, 主な検 
表 3 腎組織型別の主な検查所見の比較

\begin{tabular}{lcccccccc}
\hline \multicolumn{1}{c}{ 組織型 } & $(\mathrm{N})$ & $\begin{array}{c}\mathrm{CRP} \\
(\mathrm{mg} / \mathrm{d} l)\end{array}$ & $\begin{array}{c}\mathrm{IgG} \\
(\mathrm{mg} / \mathrm{d} l)\end{array}$ & $\begin{array}{c}\text { IgA } \\
(\mathrm{mg} / \mathrm{d} l)\end{array}$ & $\begin{array}{c}\text { IgM } \\
(\mathrm{mg} / \mathrm{d} l)\end{array}$ & IgGRF & IgMRF & IgARF \\
\hline 微小変化型 & $(5)$ & 3.8 & 1,629 & 421 & 149 & 2.7 & 2.8 & 2.7 \\
局所性増殖性腎炎 & $(6)$ & 1.0 & 1.338 & 323 & 125 & 1.8 & 2.3 & 2.1 \\
びまん性增殖性腎炎 & $(9)$ & 0.8 & 1.436 & 340 & 164 & 1.2 & 3.7 & 4.4 \\
膜性增殖性腎炎 & $(1)$ & 1.9 & 1.288 & 464 & 207 & 3.8 & 6.8 & 4.1 \\
膜性督症 & $(7)$ & 0.6 & 1,197 & 380 & 141 & 1.4 & 5.1 & 4.6 \\
間質性腎炎 & $(2)$ & 1.6 & 2.700 & 350 & 97 & 3.8 & 6.8 & 4.1 \\
\hline (IgA 腎炎) & $(10)$ & 1.3 & 1.566 & 404 & 161 & 2.3 & 3.7 & 4.0 \\
(基底膜菲薄化) & $(5)$ & 3.0 & 1.209 & 320 & 117 & 1.6 & 1.8 & 1.8 \\
\hline
\end{tabular}

表 4 疾患活動性と RF の相関

\begin{tabular}{llllc}
\hline & CRP & Lansbury 指数 & $\alpha_{2}$-Globulin & 血 沈 \\
\hline LN-RF & $0.11(\mathrm{NS})$ & $0.28(\mathrm{p}<0.05)$ & $0.05(\mathrm{NS})$ & $0.24(\mathrm{p}<0.02)$ \\
\hline IgG-RF & $0.30(\mathrm{p}<0.01)$ & $0.47(\mathrm{p}<0.01)$ & $-0.07(\mathrm{NS})$ & $0.36(\mathrm{p}<0.01)$ \\
\hline IgM-RF & $0.32(\mathrm{p}<0.01)$ & $0.42(\mathrm{p}<0.01)$ & $0.16(\mathrm{NS})$ & $0.30(\mathrm{p}<0.01)$ \\
\hline IgA-RF & $0.28(\mathrm{p}<0.02)$ & $0.46(\mathrm{p}<0.01)$ & $0.10(\mathrm{NS})$ & $0.28(\mathrm{p}<0.02)$ \\
\hline
\end{tabular}

表 5 尿蛋白と主な㭘查所見の相関

\begin{tabular}{lcc}
\hline \multicolumn{1}{c}{ 検査項目 } & 相関係数 & \multicolumn{1}{c}{$\mathrm{p}$} \\
\hline CRP (mg/d $l$ ) & -0.10 & $\mathrm{NS}$ \\
血清総蛋白 (g/d $l$ ) & -0.56 & $<0.01$ \\
Albumin (\%) & -0.20 & $<0.02$ \\
$\alpha_{2}$-Globulin (\%) & 0.47 & $<0.01$ \\
$\beta$-Globulin (\%) & 0.42 & $<0.01$ \\
$\gamma$-Globulin (\%) & -0.14 & $\mathrm{NS}$ \\
IgG (mg/d $l)$ & -0.27 & $<0.01$ \\
IgA (mg/d $l)$ & -0.05 & NS \\
IgM (mg/d $l)$ & 0.10 & NS \\
C 3 (mg/d $l)$ & -0.02 & NS \\
LN-RF (IU/m $l)$ & -0.05 & NS \\
IgG-RF & -0.16 & NS \\
IgM-RF & -0.08 & NS \\
IgA-RF & -0.13 & NS \\
\hline
\end{tabular}

查結果を比較したが (表 3), 光顕的には微小変化型 5 例，局所性メザンギウム增殖性系球体腎炎 6 例，び まん性メザンギウム增殖性系球体腎炎 9 例, 膜性增殖 性系球体腎炎 1 例, 膜性腎症 7 例, 間質性腎炎 2 例か 観察された。さらに，これらの中には，蛍光抗体法に より IgA 腎炎が 10 例，電子顕微鏡により，系球体基 底膜のびまん性の菲薄化が 5 例に観察された。これら の組織型別にみると, CRP は微小変化型と基底膜菲
薄化例で高い傾向がみられ，IgGは膜性腎症で低く， 間質性腎炎で高い傾向が認められた。

次にRAに扔いて，疾患活動性あるいは急性炎症 反応の指標と考えられている，CRP，Lansbury 指 数， $\alpha_{2}$-Globulin 分画, 血沈について各種 RF との相 関を検討した（表 4).CRP は，LN-RF とは相関を 認めなかったが，クラス別では，各クラスとも相関が 認められた。また，Lansbury 指数も，各種 RFとそ れぞれ正の相関を認めた。一方， $\alpha_{2}$-Globulinは， $\mathrm{RF}$ とは相関は認めず，血沈は各種 $\mathrm{RF}$ と正の相関を 示した.なお，CRP， Lansbury 指数， $\alpha_{2}$-Globulin 分画拀よび血沈は，Lansbury 指数と $\alpha_{2}$-Globulin と の間でのみ有意の相関がみられなかったが，他の組み 合わせでは，いずれも強い相関が認められた。

さらに，尿蛋白が各種の検査所見に及ぼす影響を検 討した（表 5 ). 尿蛋白は, 血清総蛋白, Albumin 分 画，IgG との間に有意の負の相関を認め， $\alpha_{2}$ および $\beta$-Globulin 分画とは, 強い正の相関が認められた。 IgA，IgM，各種の RF とは有意の相関を認めなかっ たが，IgG-RF および IgA-RF とは負の相関傾向が みられた。

最後に，合併症別に予後を比較した（表 6 ).AM 群を除く各群に転帰不明例があり，転帰を確認できた 症例は, I 〜 V 群の順に, 13,16,17, 27, 15, 20 
表 6 合併症別の予後の比較

\begin{tabular}{|c|c|c|c|c|c|c|}
\hline & I 群 & II群 & III群 & IV群 & V 群 & V群 \\
\hline 症例数 & 18 & 22 & 17 & 30 & 18 & 26 \\
\hline 転㷌不明例 & 5 & 6 & 0 & 3 & 3 & 6 \\
\hline 転帰碓認例 & 13 & 16 & 17 & 27 & 15 & 20 \\
\hline 死亡症例数 & 0 & 8 & 10 & 2 & 6 & 5 \\
\hline 死亡率 (\%) & 0 & 50 & 59 & 7 & 40 & 25 \\
\hline $\mathrm{p}$ & $※$ & $\hat{\imath}$ & $\widehat{\vartheta}$ & NS & $\uparrow$ & NS \\
\hline
\end{tabular}

例の合計 108 例であった，死亡が確認された症例は， 同様に I 〜 VI 群の順に，0，8，10，2，6，5例てあ り, 死亡例数を転帰確認例数で除した死亡率は, AM 群で $59 \%$ と最も高く, 次いで MRA・IP 群が $50 \%$, 膠原病重複群 $40 \%$, その他の合併症群 25\%, 腎障害 群 7\% であった. RA 単独群には, 死亡例はなく, AM 群, MRA・IP 群, 膠原病重複群は，RA 単独群 に比較して，有意に死亡率が高かった。

さらに, 死亡例と生存例に分けて, 主な臨床背景や 検查所見を比較した結果では（表 7)，死亡例は年齢 や RAの進行度が有意に高く，Lansbury指数や CRP などの疾患活動性も高かった。また，血清総蛋 白と血清補体（C 3）は有意に低值で，各種 RF も， 生存例に比較して高い值を示し, 特に IgG-RF と IgM-RFでは，両群間に有意差を認めた。

\section{IV. 考 案}

関節外症状を伴う RA の代表的なものに MRA が あり，その成因として血管炎が重要な位置を占めてい る.一方, 続発性の AM は, 最近では RA を基礎疾 患とするものが最も多く”，しかも，RAの予後に重 大な影響を及㭱している9．また，従来より，いくつ かの膠原病が混在した病態が知られており, 最近で は，MCTDにおいても，RA的な要素がしばしば重 複することが明らかになっている。さらに，従来， RAに伴う腎障害は, 上記の各種合併症による障害 や，治療薬剤による副作用としての障害が主体である と考えられていたが, 最近では, 薬剤との関連が否定 的な腎障害の存在も報告されている

これらの関節外症状の臨床背景や検查所見の特徵を 分析した報告は少なく，特に腎障害に関する検討はき わめてまれであり，今回その解析を試みた。

一般に, MRAは, RFを中心とする免疫異常が高 度であり，血管炎をもたらす重要な成因と考えられて
表 7 死亡例と生存例の比較

\begin{tabular}{|c|c|c|c|}
\hline & 死亡例 & 生存例 & $\mathrm{p}$ \\
\hline 症例数 & 31 & 77 & \\
\hline 入院時年齢（歳） & 59 & 51 & $<0.01$ \\
\hline 㕠病年数（年） & 13.4 & 10.6 & NS \\
\hline Stage & 3.2 & 2.8 & $<0.05$ \\
\hline Lansbury 指数 $(\%)$ & 92.2 & 57.2 & $<0.05$ \\
\hline CRP (mg/d $l$ ) & 5.0 & 3.1 & $<0.05$ \\
\hline 血清総蛋白 $(\mathrm{g} / \mathrm{d} l)$ & 6.4 & 7.0 & $<0.01$ \\
\hline C $3(\mathrm{mg} / \mathrm{d} l)$ & 70.4 & 84.2 & $<0.05$ \\
\hline $\mathrm{LN}-\mathrm{RF}(\mathrm{IU} / \mathrm{m} l)$ & 788 & 176 & NS \\
\hline IgG-RF & 3.4 & 2.2 & $<0.05$ \\
\hline IgA-RF & 10.2 & 5.8 & NS \\
\hline $\operatorname{IgM}-\mathrm{RF}$ & 13.5 & 6.1 & $<0.05$ \\
\hline
\end{tabular}

いるが ${ }^{10)}$ ，今回の検討でも他の群に比較して，RF は きわめて高值であった，さらに，急性炎症反応が高值 てあること，男性に頻度が高いことについては，従来 の報告と同様の結果であった．今回， RF は LN 法の 他に ELISA 法によりクラス別に測定したが，MRA・ IP 群では，いずれの方法でも有意に高い值を示し， 中でも IgG-RF は, MRA ・ IP 群と RA 単独群との差 が最も高度であった，疾患活動性を示す検查との相関 も，全体的には IgG-RF が最も強い相関を示し，IgG -RF は RA と MRA との鑑別のみでなく, 疾患活動 性の指標としても有用であると考えられた。

MRA・IP群には腎機能低下例はなく，腎生検では， 血管炎や半月体形成などの所見は認められなかった。 小さい生検組織の限界もあるため, 血管炎の所見が観 察できなかった可能性もあるが, Boersら ${ }^{11}$ は，RA の剖検 132 例を検討し, 腎以外の臟器に全身的に血管 炎が存在しても，腎では血管炎や釆球体腎炎が必ずし も認められないことを報告している。ささらに，Korpela ら²は，腎障害を認めないRA 35 例では，腎以 外の関節外症状が 16 例（46\%）に認められたのに対 し，腎障害を有するRA 56 例では，17 例（30\%）て あり，前者に比べ低率であったと報告しており，腎障 害とそれ以外の関節外症状とは，その存在様式が異な る可能性がある，多発性動脈炎など，同様に血管炎を 呈する疾患と比較しても，MRAでは腎障害が低率て あり ${ }^{12)}$, MRA では腎障害を起こしにくい要因の存在 も示唆される。 
続発性の AM は，急性期反応物質でもある serum amyloid A (SAA) を前駆蛋白とするが18), AM 群 が高齢で，雄病期間の長い進行例が多く，しかも疾患 活動性の指標が MRA・IP 群と同程度に高かったこと は, 高度の炎症が長く持続し, 関節病変の進行ととも に, SAAの産生が繰り返され, AM が発症したもの と理解される。

$\mathrm{AM}$ 群では, MRA・IP 群に比較して, RF が低值 であったが, Maury ら (14がクラス別に RF を測定し た成績でも，陽性率は 30〜40\%となっている，彼ら は, AM の発症に遺伝的な要因の関与を推定し, HLA の検討も行っているが, 明らかな関連は得られ ていない．また，RFが経過とともに低下する傾向を 認め, AM の進行に伴い, RF 産生能が低下するとい う考えもある。

一方, AM 群では, 高度の蛋白尿やネフローゼ症 候群（NS）を呈する症例が多かったことより，自己 抗体を含めた免疫グロブリンが尿中に排泄される可能 性も考えられる.今回の結果でも，IgG は血清総蛋白 などと同様に，尿蛋白量と有意の負の相関を示した. また，有意ではないが，IgG および IgA-RF が尿蛋 白量と負の相関傾向を示した。

$\mathrm{RF}$ と AM 発症との関連については， RF がなんら かの防御的役割を有しているという報告がある(14). 今 回の結果でも, RF の高い MRA・IP 群では AM の合 併例がなく，反対に，AM群のなかで，MRA と診断 された症例も認められなかった，RA と AM の合併 については, enhancing factor などの検討 ${ }^{15)}$ 含め, 今後一層の研究が必要である.

$\mathrm{AM}$ 群の腎障害は, 蛋白尿主体の尿異常が高頻度 に認められたが, Hordon ら ${ }^{16)}$ は, 血尿単独の尿異常 を呈した 21 例を腎生検し， AM は 1 例も認めなかっ たと報告している。したがって, 高度の蛋白尿は, $\mathrm{AM}$ の合併を示唆する重要な所見と考えられる。ま た，AM 群では，腡機能低下が高率に認められたが, 続発性の AM の死因の約 50\% は腎不全が占めてお $\eta^{1)}$ ，その予後も最も不良であった。 今回の結果よ り, 高齢で矦病期間の長い進行例で, 疾患活動性が十 分鎮静化されていない症例では, 蛋白尿の出現に留意 し，早期発見に努めることが重要と思われる。

翏原病重複例は，やや女性に多く， $\boldsymbol{\gamma}$-Globulinや IgG の高值, 血清補体值 (C 3) の低值が特徵的であ ったが,これらの結果は, SLE的要素を有する症例 が多かったためと思われる. 前述のように, MCTD
においても， RA 的要素の多いことが知られており， 血清補体值の低值例や $\gamma$-Globulinの高值例では, SLEや MCTD などの重複を疑い, RF 以外の自己抗 体の測定や組織学的な検索が重要であると思われる。 Cohen ら ${ }^{17)}$ も, RA と SLEの重複例 11 例を報告し, 鑑別点として，血液学的異常とともに低補体血症の重 要性を指摘している.なお，D-penicillamine（DPC) により SLEなどの自己免疫疾患が併発する場合 もあり ${ }^{18)}$, 注意が必要である. また, 今回は十分検討 できなかったが, SiS も RAに合併する頻度が高く， 時には尿細管性アシドーシスやIP，まれには原発性 胆汁性肝硬変などをもたらすこともあり，RAでは乾 燥症状の有無にかかわらず, SjS 合併の有無に留意す ベきと思われる.

その他の合併症群は, MRA ・ IP 群と同様に, 男性 が多く, 高齢者が多い特徵を示したが, この結果は, この群が感染症などのほかに, 肺癌合併例などを含む ためと思われた。

$\mathrm{RA}$ 単独群は経過が短く, 関節病変も早期の若年者 が多かったが, この結果より, 各種の関節外症状の出 現には，年齢や灰病期間が重要な要因であることが示 唆された。一方, 血清補体值の高值が認められたが, 一般に RA では, 炎症反応を反映して, 血清補体値 が高い傾向をとることが知られている，炎症反応自体 は, MRA・IP 群のほうがむしろ高いが, MRA・IP 群 では, 免疫複合体の形成に伴う補体の消費が考えら れ, 膠原病重複群では, SLEの合併により低補体血 症が認められる。すなわち, 関節外症状のない群で は,これらの要因がなく, 純粋に炎症反応を反映した 結果, 他の群に比べて高い傾向を認めたものと思われ る.

一方, 腎障害群は, 臨床背景には特徵を認めなかっ たが, 疾患活動性は全般的に低值であり, 腎障害が $\mathrm{RA}$ 自体の炎症反応に由来した障害とは異なる可能性 を示唆している。さらに，腎障害の特徵は血尿主体の 尿異常を呈し, 多量の蛋白尿や腎機能低下は低頻度で あり，AM群とはきわめて異なった結果であった。

免疫学的には, IgGの低值傾向が観察されたが,こ れは $\mathrm{AM}$ 群と同様に，尿中排泄による可能性が示唆 され，組織型別に検討した結果でも蛋白尿を伴いやす い膜性腎症で, IgGが最も低い值を示した。

系球体基底膜の菲薄化例では, 他の組織型に比較し て IgAが最も低值であったが，著者らは，この菲薄 化が金製㓮の副作用と推測している ${ }^{19)}$.一方, Van 
Riel ら 20)は金製郕で副作用を呈した症例では，副作 用のなかった症例に比べて IgA が有意に低下するこ とを報告しておうり，基底膜菲薄化が金製剤によりもた らされる可能性を示唆するものとして興味深い.

組織型別にクラス別 RF を比較した結果では, 検討 症例数が少なく，明らかな差異は見いだしえなかっ た．膜性腎症や AM では RF が低く、メザンギウム 増殖性糸球体腎炎では RF 活性が比較的高いという報 告6) あるが, 膜性腎症や AM では蛋白尿が高度のこ とが多く, RF の低值に尿中排泄が関与している可能 性は否定はできず，とくにIgG-RFに関しては，今 回の結果でも，AM群とともに膜性腎症で低い傾向 が認められた。

RA に合併する IgA 腎炎の成因は明確でなく, IgA -RF が関与する可能性も否定できないが, 今回の検 討結果では明らかでなかった. IgA 腎炎では, 血清 $\operatorname{IgA}$ 值がやや高い傾向にあったが, 原発性 IgA 腎炎 では, 血清 $\operatorname{IgA}$ の高值や IgA 型の免疫複合体の存在 が広く知られている ${ }^{21}$. Sato ら ${ }^{22)}$ は，RAに伴う IgA 腎炎に扔いても, IgA-RF 以上に IgA 型の免疫 複合体の存在を重要視しており, RF 以外の抗原抗体 反応による結果, IgA 腎炎が発生する可能性も考えら れる.

一方，金製刘や D-PCの副作用としての腎障害と HLA 抗原との関連も検討されている. 欧米では, HLA の B 8 やR 3 などが蛋白尿と強く関連してい

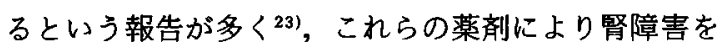
呈する RAでは RF が低いという報告もある24). 今回 の検討でも, 膜性腎症の中には藥剤性の障害が多く含 まれており，IgG-RF は低值傾向が認められたが，こ れは尿中排泄の可能性も考えられ, 他のクラスの $\mathrm{RF}$ は必ずしも低い傾向でなかった。

腎障害群では, 蛋白尿を呈する症例が比較的少な く, 血尿単独の尿異常例が多いことも， RF の低下と 尿中排泄との関連に否定的な所見であり, 組織型別に みても，RFに一定の傾向は認めなかった．この群で は, RAの疾患活動性の指標も一様に低值であり,こ れらの腎障害は RA に伴う炎症反応や免疫異常とは 関連がなく，むしろ RF の低值例に出現しやすい可能 性も示唆している。これらの所見は, $\mathrm{RF} の$ 高い MRA 症例には腎障害が比較的まれであることも深く 関連する結果と考えられる. 抗 DNA 抗体などによ り，腎障害が高頻度に出現するSLEでも，RFを有 する症例には腎障害の頻度が低いという報告もあ
る25).この点については一定の結論が得られていない が ${ }^{26)}$ ，RF の腎に対する防御的な作用を示唆するもの であり， RAに扔いても RFの低い症例では防御機構 が低下して腎障害がもたらされる可能性も考えられ る.

予後に関しては, AM 群が MRA・IP 群と同等ある いはそれ以上に予後不良であり，この 2 つの合併症が RAの診療上きわめて重要と思われた。その他では, 膠原病の重複も比較的予後不良と思われたが, 反対に これらの合併症以外の腎障害は死亡率が低く，予後は 良好と思われた．死亡例と生存例では，多くの項目で 有意差が認められたが, これらは死亡率が高かった AM 群, MRA 群, 膠原病重複群のそれぞれの特徵が 複合して表わされた結果と思われた.

以上, RA に伴う種々の関節外症状について, 臨床 背景, 免疫異常などの特徵の解明を目的に検討した. その結果, RA に併発する各種の関節外症状は, 比較 的特有の臨床背景や炎症所見, 免疫異常所見を伴うも のと思われた。

とくに，腎障害に関しては，免疫グロブリンクラス 別の RF を測定した結果でも， RA の疾患活動性や免 疫異常との関連が否定的であり, IP などの MRA で 認められる関節外症状とは異なった成因によるものと 思われた。

\section{V. 結 語}

（1） RAの関節外症状の臨床背景, 免疫異常の特徵 を解明する目的で，腎障害例を含めて検討した。

(2) 関節外症状のない RA 単独群は, RA の経過が 短く, 関節病変も早期の若年者が多く, 各種の関節外 症状の出現には, 年齢や罹病期間が重要な要因である と考えられた，検查所見では，血清補体值の高值を認 めた。

(3) MRA - IP 群は男性例が多く, 炎症所見や RF などの免疫異常が最も高度で，予後不良であった，尿 異常を 5 例に認めたが, 腎機能低下例は認めなかっ た。

（4）AM 群は高齢で罹病期間の長い進行例が多く， 炎症所見は高度ながら，IgG や IgG-RF は低い傾向 であり，尿中排泄の可能性が示唆された．蛋白尿を主 体とした尿異常を高頻度に認め，腎機能障害も高頻度 で最も予後不良であった。

（5）膠原病重複群は女性が多く, $y$-Globulin の高 值, 補体の低值が特徴的であった. AM 群, MRA・ 
IP 群に次いで予後不良であった。

（6）腎障害群は臨床背景に特徴がなく，疾患活動性 や RF などの免疫異常が軽度であった．尿所見は血氺 が主体で，腎機能低下例は低頻度であり，予後は比較 的良好であった，組織学的には多彩な所見が観察され たが，組織型別の免疫異常の特徴は明らかでなかつ た.

文 献

1) Browning, M.J., Banks, R.A., Tribe, C.R. et al. : Ten years' experience of an amyloid clinic-a clinicopathological survey. Q.J. Med., 54: 213 227, 1985.

2) Hall, C.L., Fothergill, N.J., Blackwell, M.M. et al.: The natural course of gold nephropathy: long term study of 21 patients. Br. Med. J., 295: 745 748, 1987.

3) Hall, C.L., Jawad, S., Harrison, P.R. et al. : Natural course of penicillamine nephropath $\mathrm{y}:$ a long term study of 33 patients. Br. Med. J., 296: 1083 1086, 1988.

4) Davis, J.A., Cohen, A.H., Weisbart, R. et al. : Glomerulonephritis in rheumatoid arthritis. Arthritis Rheum., $22: 1018 \sim 1023,1979$.

5) Sellars, L., Siamopoulos, K., Wilkinson, R. et al. : Renal biopsy appearances in rheumatoid disease. Clin. Nephrol., 20:114 120, 1983.

6) Korpela, M., Mustonen, J., Helin, H. et al. : Immunological comparison of patients with rheumatoid arthritis with and without nephropathy. Ann. Rheum. Dis., 49:214 218, 1990.

7) Bampton, J.L.M., Cawston, T.E., Kyle, M.V. et al. : Measurement of rheumatoid factors by and enzyme-linked immunosorbent assay (ELISA) and comparison with other methods. Ann. Rheum. Dis., $44: 13 \sim 19,1985$.

8）藤松順一・佐藤俊孝・小出 醇・他 4 名：酵素 免疫測定法（ELISA）によるIgG-RF 測定系 の確立. リウマチ科, 4:112〜124, 1990.

9) Mutru, O., Laakso, M., Isomäki, H. et al. : Ten year mortality and causes of death in patients with rheumatoid arthritis. Br. Med.
（7） RAに伴う腎障害は，IPなどの MRAで認め られる関節外症状とは異なった成因が考えられ，RF の低值例に発生しやすい可能性が示唆された。

稿を終えるにあたり, 御指導, 御校閲を賜りました 荒川正昭教授に深謝いたします。

J., $290: 1797 \sim 1799,1985$.

10) Scott, D.G.I., Bacon, P.A., Tribe, C.R. : Systemic rheumatoid vasculitis: a clinical and laboratory study of 50 cases. Medicine, 60 : 288 297, 1981.

11) Boers, M., Croonen, A.M., Dijkmans, B.A.C. et al. : Renal findings in rheumatoid arthritis : clinical aspects of 132 necropsies. Ann. Rheum. Dis., $46: 658 \sim 663,1987$.

12）橋本博史・長沢俊彦・安倍 達・他 2 名：結節 性多発動脈炎, ウェゲナー性肉芽腫症, アレル ギー性肉芽腫性血管炎，悪性関節りウマチの臨 床像と経過・予後の比較. リウマチ, $28: 145 〜$ 155, 1988.

13) Falck, H.M., Maury, C.P.J., Teppo, A.M. et al. : Correlation of persistently high serum amyloid $\mathrm{A}$ protein and C-reactive protein concentrations with rapid progression of secondary amyloidosis. Br. Med. J., 286: 1391 1393, 1983.

14) Maury, C.P.J., Teppo, A.M., Wafin, F. et al. : Class-specific rheumatoid factors, DR antige$\mathrm{ns}$, and amyloidosis in patients with rheumatoid arthritis. Ann. Rheum. Dis:, $47: 546 \sim$ $552,1988$.

15) Shirahama, T., Miura, K., Ju, Shyr-T. et al. : Amyloid enhancing factor-loaded macrophages in amyloid fibril formation. Lab. Invest., $62: 61 \sim 65,1990$.

16) Hordon, L.D., Sellars, L., Morley, A.R. et al. : Haematuria in rheumatoid arthritis : an association with mesangial glomerulonephritis. Ann. Rheum. Dis., 43: 440 443, 1984.

17) Cohen, M.G., Webb, J. : Concurrence of 
rheumatoid arthritis and systemic lupus erythematosus : report of 11 cases. Ann. Rheum. Dis., 46 : 853 858, 1987.

18) Chalmers, A., Thompson, D., Stein, H.E. et al. : Systemic lupus erythematosus during penicillamine therapy for rheumatoid arthritis. Ann. Intern. Med., $97: 659 \sim 663,1982$.

19）中野正明-小澤哲夫・西 慎一・他 9 名：慢性 関節りウマチの腎障害一80症例の臨床病理学 的検討一. 日内会誌, $28: 21 \sim 29,1989$.

20) Van Riel, P.C.M., Van de Putte, L.B.A., Gribnau, F.W.J. et al. : Serum IgA and gold-induced toxic effects in patients with rheumatoid arthritis. Arch. Intern. Med., $144: 1401 \sim 1043,1984$.

21) Hall, R.P., Stachura, I., Cason, J. et al. : IgA -containing circulating immune complexes in patients with IgA nephropathy. Am. J. Med., $74: 56 \sim 63,1983$.

22) Sato, M., Kojima, H., Koshikawa, S. : IgA nephropathy in rheumatoid arthritis. Nephron, $48: 169 \sim 170,1988$.

23) Barger, B.O., Acton, R.T., Koopman, W.J. et al. : DR antigens and gold toxicity in white rheumatoid arthritis patients. Arthritis Rheum., $27: 601 \sim 605,1984$.

24) Moutsopoulos, H.M., Skopouli, F.N., Sarras, A.K. et al. : Anti-Ro (SSA) positive rheumatoid arthritis (RA) : a clinicoserological group of patients with high incidence of $D$ penicillamine side effects. Ann. Rheum. Dis., $44: 215 \sim 219,1985$.

25) Helin, H., Korpela, M., Mustonen, J. et al. : Rheumatoid factor in rheumatoid arthritis associated renal disease and in lupus nephritis. Ann. Rheum. Dis., 45: 508 511, 1986.

26) Turner-Stokes, L., Jones, M., Addison, I. et al. : Does rheumatoid factor protect lupus patients from the development of nephritis? Ann. Rheum. Dis., 48 : 14 16, 1989. 